\title{
HOMENAGEM AO PROFESSOR ODON RAMOS MARANHÃO
}

O professor Odon Ramos Maranhão nasceu em 23 de março de 1924, na cidade de São Paulo e era filho de Odon Cavalcanti Maranhão e Pacífica Ramos.

Fez o curso de Medicina na Faculdade de Medicina da Universidade de São Paulo, bacharelando-se em 1953.

Homem dedicado à família e ao profissionalismo tornou-se em 1963 livre-docente de Medicina Legal na Faculdade de Direito e dez anos depois professor adjunto da mesma cadeira, chegando a titular do Departamento de Medicina Forense em 1981.

Seus livros Curso Básico de Medicina Legal e Psicologia do Crime tornaram-se mola-mestra de todo aluno de graduação e pós-graduação e conhecidos em todo o País, tornando o professor conhecido em todas as faculdades de Direito.

O professor Odon Ramos Maranhão, quando solicitado por alunos, funcionários e colegas era excepcional no atendimento, porque se tornou amigo de todos, deixando uma lacuna irreparável nas Arcadas no dia 20 de novembro, uma vez ter sido chamado pelo Pai Celestial.

A seguir, palavras do professor José Maria Marlet:

O professor Odon não foi apenas um excepcional educador; na realidade aliava este raro predicado paralelamente ao de possuir uma personalidade que extrapolava suas qualificações docentes; como colega, amigo, orientador, conselheiro ..

Em pouco menos de vinte anos que mantive contato com esse nobre companheiro, sempre demonstrou boa-vontade ao se lhe apresentar os mais diversos tipos de problemas. Com tranqüilidade e proficiência, o professor Odon indicava soluções simples e claras, não apenas no campo da Medicina Forense, considerando que também dominava o mundo do Direito, onde assimilou sua linguagem e, como poucos, sabia relacionar os universos médico, jurídico e psicológico. Como perito da Justiça e como emérito parecerista, elaborou trabalhos de magnífico conteúdo técnico, prodigalizando sua cultura, tanto na sala de aula quanto fora dela.

É difícil exprimir em palavras a emoção e tristeza de estar referindo sobre a morte do professor Odon Maranhão, muito embora ele esteja presente e vivo 
em nossas mentes e de todos que tiveram a felicidade de tê-lo como companheiro, como conselheiro e, acima de tudo, como amigo.

Pelo seu espírito profundamente religioso, acredito que o professor Odon deva estar ministrando aulas aos anjos, inspirado por Deus que nos privou de seu convívio para acrescentá-lo à falange de almas que se distinguiram por suas obras e pela nobreza de caráter emoldurado pelo mais cristalino e cristão dos princípios morais que dignificam a espécie humana. 


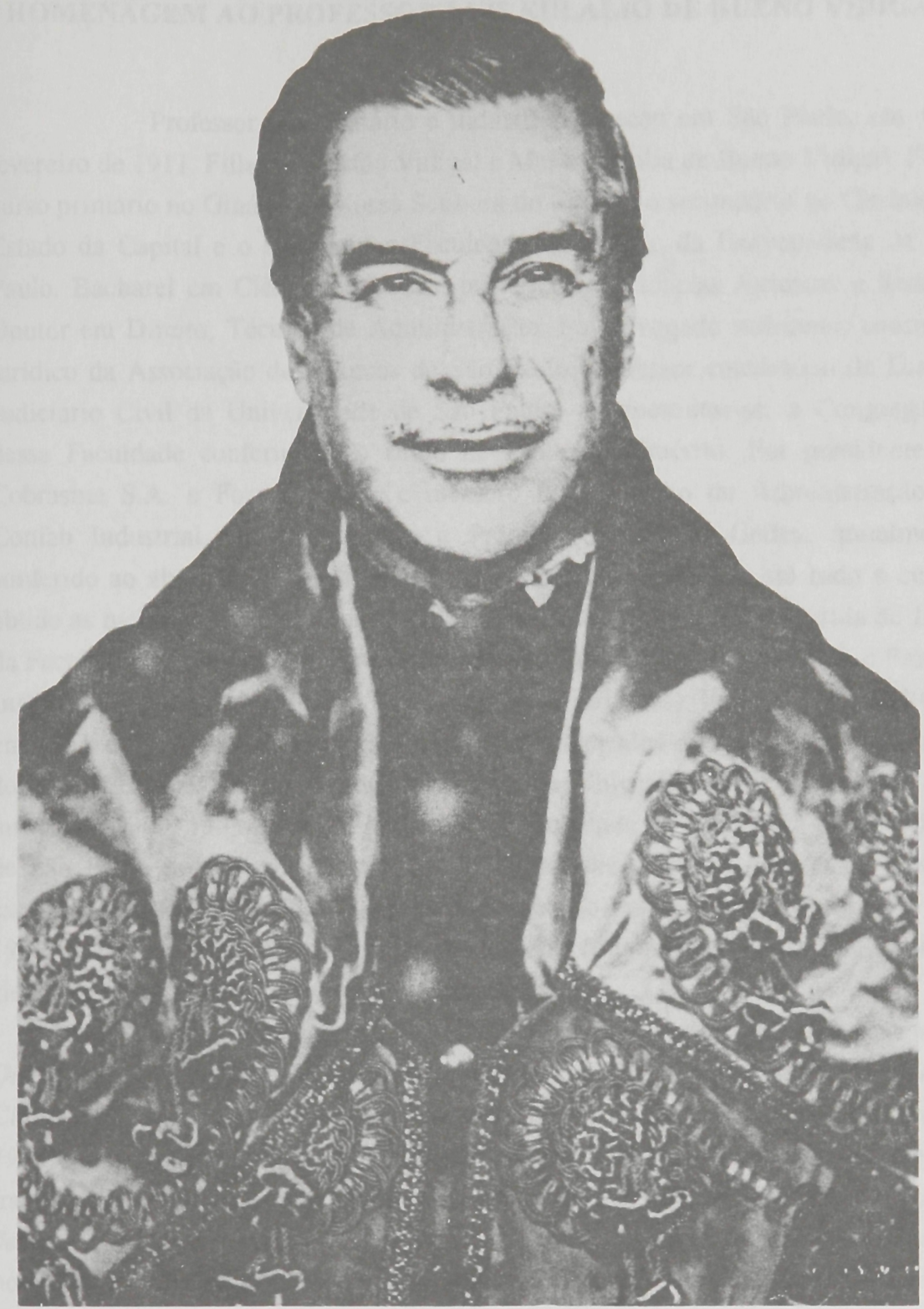

Professor Odon Ramos Maranhão 